\title{
The correct authorship and nomenclature of Artemisia umbrosa (Asteraceae), with comments on some misapplied names and distribution of the species in Eastern Europe
}

\author{
Sergei L. MOSYAKIN ${ }^{1}$, Filip VERLOOVE², Ganna V. BOIKO ${ }^{1}$ \\ ${ }^{1}$ M.G. Kholodny Institute of Botany, National Academy of Sciences of Ukraine \\ 2 Tereshchenkivska Str., Kyiv (Kiev), 01004, Ukraine \\ s_mosyakin@hotmail.com \\ bav22@ukr.net \\ ${ }^{2}$ Botanic Garden of Meise \\ Nieuwelaan 38, B-1860 Meise, Belgium \\ filip.verloove@plantentuinmeise.be
}

Mosyakin S.L., Verloove F., Boiko G.V. The correct authorship and nomenclature of Artemisia umbrosa (Asteraceae), with comments on some misapplied names and distribution of the species in Eastern Europe. Ukr. Bot. J., 2018, 75(3): $213-229$.

Abstract. Artemisia umbrosa, initially described as A. vulgaris var. umbrosa, is an East Asian species that has been introduced and is now locally naturalized in some European countries. It has a complicated nomenclatural and taxonomic history. The name Artemisia umbrosa has been misapplied to related taxa of Artemisia sect. Artemisia, including A. verlotiorum, and several other names were erroneously applied to that taxon. The authorship of the species was variously cited in earlier literature (as "Turcz. ex DC.", "Turcz. ex Besser", "(Besser) Turcz. ex DC.", "(Turcz. ex DC.) Pamp.", "(Turcz. ex Besser) Pamp.", etc.). We demonstrate here that the basionym A. vulgaris var. umbrosa was first validated in 1832 (not 1834) by Besser. The species-rank combination $A$. umbrosa was validated not by Pampanini in 1930 but by Verlot in 1875, and thus the proper authorship citation of the name is $A$. umbrosa (Turcz. ex Besser) Turcz. ex Verlot. Despite the fact that Verlot misapplied the name $A$. umbrosa to the species later described as $A$. verlotiorum, his combination is valid and legitimate. Some other names misapplied to $A$. umbrosa are briefly considered (such as $A$. codonocephala auct. non Diels, $A$. dubia auct. non Wall. ex Besser, $A$. lavandulifolia auct. non DC., nom. illeg., etc.). The lectotype and other available original specimens of $A$. umbrosa (especially those from the Turczaninow and Besser historical herbaria at $\mathrm{KW}$ ) are discussed. A brief overview of records of $A$. umbrosa (reported under several names) in Eastern Europe is provided.

Keywords: alien species, Artemisia, Asteraceae, typification, nomenclature, taxonomy

\section{Introduction}

Artemisia umbrosa [initially described as A. vulgaris var. umbrosa, see comments on its authorship below] is an East Asian species that was reported within its native range from the Russian Far East (south) and Siberia (southeast), China (mostly northern regions), and Mongolia (Pampanini, 1930, 1933; Polyakov, 1961; Leonova, 1982; Korobkov, 1992; Krasnoborov, 1997; Filatova, 2003; Zuev, 2005, 2012; Ling et al., 2011; Urgamal et al., 2014, etc.). It is also known as an alien species forming colonies in several regions of Europe (Mosyakin, 1990, 1991, 2006; Leonova, 1994; Gudžinskas, 1990, 1997; Tretyakov, 1999; Yena, 2005; Boiko, 2009, 2012, 2013; Sîrbu, Oprea, 2011; Mayorov, 2014; Morozova, 2014, etc., see below), but data on (C) S.L. MOSYAKIN, F. VERLOOVE, G.V. BOIKO, 2018

Укр. бот. журн., 2018, 75(3) its synanthropic distribution are in need of critical reassessment and verification because of its confusion with other similar species, and also because of nomenclatural problems (see further details below).

In Europe A. umbrosa was for the first time reported from Ukraine, where several colonies of that species were found by Mosyakin (1990) in Kyiv along railroads (Fig. 1). Mosyakin (1990, 1991, etc.) also reported several other morphologically similar alien species (such as $A$. argyi H. Lév. \& Vaniot, etc.) known and/or newly discovered by that time in Ukraine and adjacent countries, and provided a key for identification of these species related to $A$. vulgaris $\mathrm{L}$. and belonging to Artemisia sect. Artemisia. Before 1990, almost all long-rhizomatous and stoloniferous alien species of that species aggregate found in Eastern Europe (except the correctly identified earlier records of 


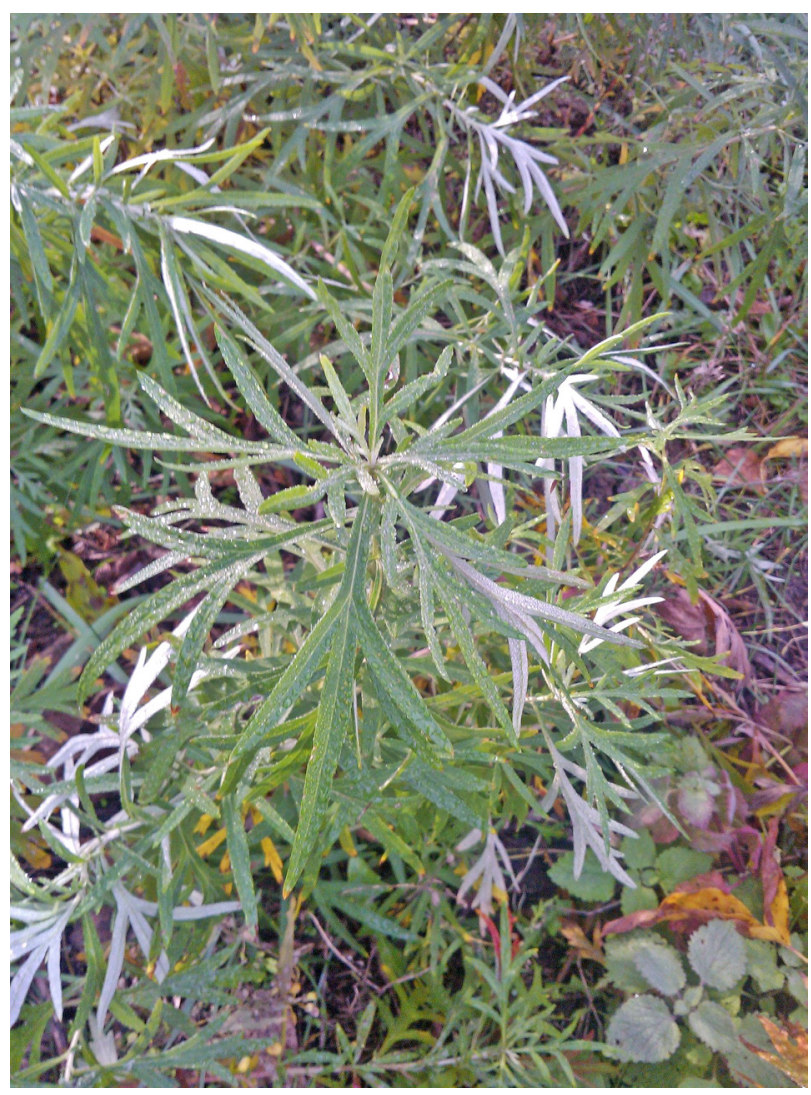

Figure 1. Artemisia umbrosa along the railway in Darnytsa District, Kyiv, 19 October 2017; this still existing colony was first found by S. Mosyakin in 1989.

A. selengensis Turcz. ex Besser: see Vynaev, Tretyakov, 1978; Puzyrev, 1985, and Gudžinskas, 1990) and in Europe in general were identified as A. verlotiorum Lamotte (see Brenan, 1950; Verloove, 2013-onward, etc.). Artemisia umbrosa is now also known in some other European countries, where it was sometimes reported under several other names.

\section{Artemisia umbrosa in Eastern Europe: early records and current distribution}

In Eastern Europe $A$. umbrosa was probably found for the first time in Latvia (first collected in 1955 by A. Rasiņš, see Fatare, Gavrilova, 1985; Tabaka et al., 1988) and then in Belarus (Vynaev, Tretyakov, 1978); in both cases it was identified as "A. verlotiorum" (see Leonova, 1987). Probably the first collection of $A$. umbrosa in the European part of Russia has been made by Gusev in October 1978 in St. Petersburg (formerly Leningrad) at the Sortirovochnaya-Moskovskaya railway station. The plants were initially identified by
Tzvelev as " $A$. verlotiorum" and the record was published under that misapplied name (Gusev, 1980: 250; later recognized as $A$. umbrosa by Tzvelev, 2000: 614). New finds of $A$. umbrosa in Russia were reported later, also as "A. verlotiorum", from Moscow Region (Ignatov et al., 1983, 1990), Kaluga Region (Volosnova, 1986), and Udmurtia (Puzyrev, 1985, 1989; later recognized as A. umbrosa: see Baranova et al., 1992; Baranova, Puzyrev, 2012).

Taxonomic conclusions of Mosyakin (1990) on alien plants of the $A$. vulgaris aggregate found in Ukraine (and his revision of selected specimens from Belarus, Leningrad, and Udmurtia, which proved to be A. umbrosa: see Mosyakin 1990: 12) resulted in subsequent new East European records and new identifications of earlier collections. In particular, it has been demonstrated that true $A$. verlotiorum was reliably known at that time in the eastern part of Europe only in Crimea (Mosyakin, 1990), but later it was also reported from the Caucasus (Dubovik, Mosyakin, 1991; Gabrielian, Vallès Xirau, 1996; Kikodze et al., 2010), the adjacent parts of Turkey (Jäger, 1988; Byfield, Baytop, 1998; Uludag et al., 2017, etc.), and Turkmenistan (Nikitin, Geldikhanov, 1988; now reported as a "common weed": Kurbanov, Vlasenko, 2006).

Mayorov et al. (1993) provided data on a new locality of $A$. argyi near Kozelsk, revised the collections of Volosnova from Maloyaroslavets (both in Kaluga Region), and identified the plants as belonging to A. umbrosa. They also commented that the latter species was earlier erroneously reported from the region by Volosnova (1986) as A. verlotiorum and that new records and revisions of older identifications of taxa from the affinity of A. vulgaris should be expected after the publication by Mosyakin (1990) [in Russian: "Ранеe ошибочно указана для области под названием A. verlotiorum Lamotte (Волоснова, 1986). После публикации С.Л. Мосякина (1990) следует ожидать новые находки и уточнение старых определений для полыней из родства $A$. vulgaris L.": Mayorov et al., 1993: 121]. Now $A$. umbrosa is known from several regions of the European part of Russia, where it is considered a "railway" plant found mainly along railway beds and slopes and sometimes forming dense thickets (see an overview and map in: Morozova, 2014: 27). In recent Russian literature the species is often accepted as "A. dubia" (Mavrodiev et al., 1999; Vasyukov, 2004; Mayorov, 2006, 2014; Mayorov et al., 2012; Borisova, 2012; Notov, Notov, 2012; Tretyakova, 2012; Tremasova 
et al., 2013; Seregin, 2014; Vinogradova et al., 2017, etc.). In the European part of Russia the species is known from Ivanovo, Kaluga, Kostroma, Moscow, Penza, Ryazan, Samara, Saratov, St. Petersburg (Leningrad), Tambov, Tula, Tver, Ul'yanovsk, Vladimir, Volgograd, Voronezh, Yaroslavl, Yekaterinburg (Sverdlovsk) regions, republics of Mordovia, Tatarstan and Udmurtia, and from some other administrative units (Mayorov, 2014; Khorun et al., 2012, and references listed above), northward up to Kandalaksha in Murmansk Region (Kozhin et al., 2014) and Petrozavodsk in Karelia (Kravchenko et al., 2014). However, Mayorov (2006: 507; 2014: 366) commented that the species is definitely more widespread there, but is often overlooked by collectors [in Russian: "Без сомнения, распространена шире, но просматривается"].

Artemisia umbrosa was also reported (under several names) from Belarus (Vynaev, Tretyakov, 1978, as "A. verlotiorum"; Tretyakov, 1999, as A. umbrosa), Lithuania (Gudžinskas, 1990, as "A. verlotiorum"; Gudžinskas, 1997, as "A. codonocephala"), Latvia (Fatare, Gavrilova, 1985; Tabaka et al., 1988, as "A. verlotiorum"; Evarts-Bunders et al., 2012, and references therein), and several regions of Ukraine, in particular, Kyiv (Mosyakin, 1990, 1991; Mosyakin, Fedoronchuk, 1999, as A. umbrosa; Mosyakin, 1992, 2006, as "A. codonocephala"), Kherson (Moysienko, 2000, as A. umbrosa), Crimea (Yena, 2005, 2012, as "A. codonocephala"; Seregin et al., 2015, as "A. dubia"), Donetsk (Boiko, 2009; Ostapko et al., 2010, as "A. lavandulifolia"; Boiko, 2012, as A. umbrosa), Lviv (Kuzyarin, 2012; Mamchur et al., 2017, as A. umbrosa), etc. In Romania $A$. umbrosa was reported as "A. lavandulifolia" (Sîrbu, Oprea, 2011). The recently published first record of "A. dubia" from Kazakhstan (found in Kostanay: see Perezhogin, Kulikov, 2017) most probably (or almost certainly) also belongs to $A$. umbrosa, judging from the image of a herbarium specimen available online (http://rcb.kspi.kz/pages/ Families/Asteraceae/Artemisia_umbrosa.html, now identified as A. umbrosa).

It is also worth noting that $A$. umbrosa (reported as "A. dubia") and A. vulgaris were studied at the Lithuanian Institute of Agriculture as potential biomass producers for biofuel (Kryževičienè et al., 2010; Kadžiulienè et al., 2017, etc.). It was concluded that both species are well suited for biofuel production (however, A. umbrosa proved to be a much better biomass producer than A. vulgaris) and they have been recommended for cultivation (Kryževičienė et al., 2010). That, in our opinion, may result in further uncontrolled spread of A. umbrosa.

It seems that in the eastern part of Europe $A$. umbrosa is currently the most successful invader among alien species of Artemisia sect. Artemisia known from that territory, followed by $A$. argyi; other taxa are less widespread and are known from a few localities each. These taxa are reported in dozens of East European publications, and at least some of those records are in need of re-assessment (as well as at least some records of $A$. verlotiorum from Central Europe; see Verloove, 2012-onward). A critical overview and detailed analysis of the available records and specimens of Artemisia sect. Artemisia from Eastern Europe is in progress and will be published separately.

\section{The correct authorship and dates of publication of Artemisia umbrosa}

Artemisia umbrosa has a complicated nomenclatural and taxonomic history, which is worth discussing in more detail. In particular, several other names, including A. verlotiorum (see above), were misapplied to that taxon. The authorship of the species-rank combination A. umbrosa was also debatable, being cited variously in earlier literature as "Turcz.", "Turcz. ex DC.", "Turcz. ex Besser", "(Besser) Turcz. ex DC.", "(Turcz. ex DC.) Pamp.", "(Turcz. ex Besser) Pamp.", etc. In our recent article (Mosyakin et al., 2017: 257) we also cited that species as "A. umbrosa (Turcz. ex Besser) Pampanini (1930: 448) (= A. vulgaris var. umbrosa Turczaninow ex Besser 1832: 52; 1834: 52)". Clarification of the authorship, nomenclature, and taxonomic identity of $A$. umbrosa is especially important in view of the ongoing studies of alien species of Artemisia sect. Artemisia naturalized in Europe and in some other parts of the world (Verloove et al., research in progress).

In our earlier article (Mosyakin et al., 2017) we have already demonstrated that the date of valid publication of the name Artemisia vulgaris L. var. mongolica Besser, as well as of many other names in Artemisia published in Besser's Tentamen de Abrotanis..., is 1832, not 1834 or 1833 , as it was often accepted earlier. The treatment by Besser was indeed published in volume 3 of Nouveaux Mémoires de la Société Impériale des Naturalistes de Moscou issued in 1834 (Besser, 1834), but it was preceded by a preprint (separate article) published already in 1832 and distributed to some botanical institutions and individual botanists (Besser, 1832). 
The pagination and content of the preprint are in fact identical to those of the final version of the article (only some minor typographic errors were corrected in the journal version). The preprint was undated (except the date of the Preface, signed by Besser as "Scripsi Cremeneci d. 30 Aprilis 1832" - "Written in Kremenets on 30 April 1832": Besser, 1832: 8; and the date at the end of the treatment "Cremeneci d. 16 Julii 1832" "Kremenets, 16 July 1832": Besser 1832: 89) but it was already delivered from Moscow to Paris in January 1833 (de Candolle, 1833; see details in Mosyakin et al., 2017), so its actual publication in 1832 can be accepted with certainty. Pritzel (1851: 22) in his bibliography also reported the date of publication of that preprint as 1832. Thus, the epithet "umbrosa" was first validated in Artemisia by Besser in 1832 for a variety of $A$. vulgaris.

The species name "A. umbrosa" attributed to Turczaninow (as "Turcz.! in litt.") was mentioned by de Candolle (1838: 113), but only in synonymy of A. vulgaris var. umbrosa. The name is still listed in the International Plant Names Index (IPNI, 2018-onward, accessed 23 March 2018) as "A. umbrosa Turcz. ex DC."; however, in that publication it was an invalid name (Art. 36.1(c) of the ICN; McNeill et al., 2012). Turczaninow (1846: 197) also listed his "A. umbrosa Turcz. pl. exsicc." only in synonymy of the accepted name $A$. vulgaris var. umbrosa.

It was usually assumed in recent publications (Mosyakin, 1990; Leonova, 1994; Boiko, 2012, etc.) that the species-rank combination Artemisia umbrosa was validated by Pampanini (1930). However, Pampanini cited in his articles an earlier publication by Verlot, a seed catalogue of 1875 from the Grenoble Botanical Garden ("Verlot J.B., Jardin botanique de la Ville de Grenoble: Catalogue des graines récoltées en 1875, p. 12. Grenoble, 1875": see Pampanini, 1923: 78), in which, judging from Pampanini's citation, Verlot accepted the name $A$. umbrosa at species rank and ascribed (attributed) its authorship to Turczaninow. Moreover, as it has been demonstrated later, Verlot misapplied that name to another species that was subsequently described as $A$. verlotiorum, originally published as "A. verlotorum" (Lamotte, 1877: 513) but correctable to "verlotiorum" following Art. 60.12, Ex. 37-38, and Recommendation 60C.1(b) of the ICN (McNeill et al., 2012). Lamotte (1877) and Bonnet (1883: 208) noticed that Verlot misapplied the name $A$. umbrosa to plants of A. verlotiorum. Unfortunately, Bonnet erroneously accepted for that species the name $A$. selengensis Turcz. ex Besser (1832: 50; 1834: 50) [cited by Bonnet as:
"A. selengensis Turcz., Cat. Baical, no 630; A. Verlotorum Lamotte; A. umbrosa J.-B. Verl. (non Turcz.)"], which in fact refers to the currently recognized and morphologically well outlined East Asian species that is also locally known as alien in Belarus (Vynaev, Tretyakov, 1978; Tretyakov, 1999), Lithuania (Gudžinskas, 1990, 1997), Ukraine (Mosyakin, 1990; Bortnyak, Voytyuk, 1991), and some regions of the European part of Russia (Puzyrev, 1985; Mayorov, 2006, 2014; Mayorov et al., 2012, Seregin, 2012, 2014, etc.). It was also discovered in 2012 in the Netherlands (Verloove, 2013-onward) and may be expected in some other European countries.

The Grenoble Catalogue... of 1875 seems to be a very rare publication. Brenan in his article listed that reference but reported that he has not seen it (Brenan, 1950: 223). Our efforts to locate at least one still existing copy of the Catalogue... proved to be unsuccessful, despite our thorough search in several major libraries of Ukraine and Belgium and numerous requests sent to libraries of several botanical institutions and libraries of Paris, Geneva, Grenoble, London, etc. However, we found that the Catalogue... was cited and/or directly referenced in several botanical periodicals of the 1870s. In particular, an anonymous author in a review of recent botanical publications reported in Bulletin de la Société Botanique de France: "Dans le Catalogue des graines récoltées en 1875, M.J.-B. Verlot signale l'Artemisia umbrosa Turcz., espèce douteuse observée par lui sur quelques points des environs de Grenoble, qui diffère de l'A. vulgaris par ses feuilles incisées profondément à lobes aigus, entiers, presque réguliers, les supérieures lancéolées ou linéaires entières, son inflorescence pauciflore, à rameaux penchés, ses fleurs solitaires un peu plus petites, presque unilatérales, et par l'époque de floraison de deux à trois mois plus tardive" (Anonymous in Fournier, 1876: 3). The Grenoble Catalogue... of 1875 (including Verlot's acceptance of $A$. umbrosa) was also mentioned and briefly reviewed in some other bibliographic reviews of the 1870s (Anonymous in Just, 1877; Bohnensieg, Burck, 1879, etc.).

An excerpt from the 1875 publication (the paragraph directly related to Verlot's information about $A$. umbrosa) was reproduced, most probably verbatim and in toto, in Bulletin de la Société Dauphinoise pour l'Échange des Plantes in 1876. In particular, Verlot wrote: "Artemisia umbrosa Turcz. - A. vulgaris L. Var. umbrosa DC. Prodr. 6, p. 113. - Nous nommons ainsi (sans être certain que ce nom soit exact) une plante que nous observons depuis deux ans dans plusieurs localités autour Grenoble, et qui est voisine de l'Artemisia vulgaris L." (Verlot, 1875, cited 
according to Verlot, 1876: 73) [translation: "We name here (not being sure that this is the proper name) a plant that we have been observing for two years in several localities near Grenoble, and which is close [closely related] to Artemisia vulgaris L."]. He then discussed some morphological differences of that species from A. vulgaris sensu stricto and reported that he observed and collected the plants in numerous localities in and around Grenoble.

Verlot's reference to the authorship of Turczaninow is an indirect reference (Art. 38.14 and 41.3 of the ICN) to the existing basionym $A$. vulgaris var. umbrosa [Turcz. ex] Besser (1832: 50; 1834: 50; see also de Candolle, 1838: 113). According to Art. 7.3 of the ICN (McNeill et al., 2012), a nomenclatural combination is typified by the type of its basionym even though it may have been applied erroneously to a taxon now considered not to include that type. Consequently, Verlot validated the new combination $A$. umbrosa (Besser) Turcz. ex Verlot (homotypic with $A$. vulgaris var. umbrosa), despite the fact that he misapplied that name to another species (A. verlotiorum).

Judging from the available bibliographic references mentioned above, there is no reason to doubt that the Catalogue... of 1875 by Verlot actually existed, despite our failure to find its extant copies. Even if we assume that that publication never existed (which is not the case) or has not been published effectively (in the sense of Art. 29-30 of the ICN), the text reproduced in Bulletin de la Société Dauphinoise pour l'Échange des Plantes in 1876 and directly attributed to Verlot constitutes effective and valid publication of the nomenclatural combination A. umbrosa. Thus, the species-rank name was published in 1875 (or 1876?) and thus it is of priority over A. codonocephala Diels and some other names, if these taxa are considered conspecific.

\section{Notes on typification and original specimens of Artemisia umbrosa}

Korobkov (2014: 15) designated the following specimen as the lectotype of $A$. umbrosa (A. vulgaris var. umbrosa): "Lectotypus (Korobkov, hic designatus) et isolectotypi (3): Восточная Сибирь, Бурятия, "In umbrosis Charatzai, in insulis Selenga, 1829 [fl.], Turczaninov (Herb. Ledebour)" (LE*)". The following specimens were listed as syntypes: "Syntypi (3): Восточная Сибирь, Забайкальский край, "In humidis Dahuria Nerrcziensis [sic! - S.M.], 1831 [fl.], Turczaninov""

\footnotetext{
* Herbarium acronyms here and below follow Index Herbariorum (Thiers, 2018-onward).
}

Укр. бот. журн., 2018, 75(3)
(Korobkov, 2014: 15). As in many cases of other taxa of Artemisia reported in his article, Korobkov (2014) used almost exclusively the specimens currently deposited in LE; no specimens from herbaria of Besser (KW, KW-BESS) and Turczaninow (KW, KW-TURCZ) in Kyiv and de Candolle in Geneva (G, G-DC) were reported or consulted, even for taxa described by Besser, Turczaninow, and de Candolle.

However, when describing his A. vulgaris var. umbrosa, Besser (1832: 52) cited concrete specimens belonging to four morphologically somewhat different forms: "a) Talis ad Selengam in umbrosis Turtschan. b) Eadem paniculæ ramis inferioribus longioribus, sine loco indicato Adams (herb. Acad. Imp. Sc.). - c) Eadem caule paniculato foliis summis brevioribus, sine patria indicata Gmel. jun. (in eodem herbario) - d) Foliorum trifidorum lacinia media vix reliquis longiore, panicula majore, spicis inferioribus magis elongatis, suberectis. Ad eandem Selengam legit Adams (idem herb.)". These specimens should be considered syntypes and their duplicates are thus isosyntypes. Localities "Charatzai" and "Dahuria Nercziensis" (Nerchinsk) were not reported in the protologue. Most of the specimens collected by Turczaninow have original (or sometimes curatorial) labels with the handwritten text "In umbrosis ad Selengam" (see below). De Candolle (1838: 113) reported $A$. vulgaris var. umbrosa as "in umbrosis ad Selengam Ircutiæ legit cl. Turczaninow". Turczaninow (1846: 197, see also Turczaninow, 1856) in his Flora Baicalensi-Dahurica also cited only the general geographical information: "In umbrosis ad Selengam".

Ledebour (1844: 584) accepted A. umbrosa as A. selengensis var. $[\beta]$ umbrosa (Turcz. ex Besser) Ledeb. and reported it as "Hab. in Sibiria transbaikalensis in insulis fl. Selenga! et alibi inque Davuria ad Charatzai! (Turcz.)" (Ledebour, 1844: 585). Most probably the latter specimen provided to Ledebour by Turczaninow was designated by Korobkov (2014) as the lectotype of A. umbrosa. The toponym "Charatzai" evidently refers to the village (ulus) of Kharatsay (Харацай in Russian, Xapacaa in Buryat) on the left bank of the Dzhida River (also Dschida, Джида in Russian; a tributary of the Selenga) in Zakamensky District (Закаменский район in Russian; Захааминай аймаг in Buryat) of the Republic of Buryatia, Russia. That village is located ca. $8 \mathrm{~km}$ above the confluence of the Dzhida and the Selenga. However, the species was probably also collected by Turczaninow in some other localities, in particular, near the town of Selenginsk (Селенгинск in Russian) in Kabansk District (Кабанский район in 
Russian; Хабаансха аймаг in Buryat) of Buryatia, and on the Selenga within the present-day Zabaykalskiy Kray (Trans-Baikal Province, Забайкальский край) of Russia.

Thus, the lectotype designation by Korobkov (2014) was not the best available choice (see comments and the list of other original specimens below). However, the current wording of Art. 9.19 of the ICN (McNeill et al., 2012) gives no solid reason for rejection of his lectotypification because the lectotype specimen belongs to original material in the extended sense of Art. 9.3 of the ICN (McNeill et al., 2012).

Artemisia umbrosa (Turcz. ex Besser) Turcz. ex Verlot, Catalogue des graines du Jardin botanique de Grenoble, 1875: 12. 1875 (Verlot, 1875: 12, non vidi); Verlot in Bull. Soc. Dauphin. Échange Pl. [Première série] 3: 73. 1876 (Verlot, 1876: 73).

Basionym: Artemisia vulgaris L. var. umbrosa Turcz. ex Besser, Tentamen de Abrotanis seu de sectione II ${ }^{d a}$ Artemisiarum Linnoei [Moscow]: 52. 1832 (Besser, 1832: 52, preprint); Besser, Nouv. Mém. Soc. Imp. Naturalistes Moscou 3: 53. 1834 (Besser, 1834: 52, bound volume).

Type:-RUSSIA. Buryatia [Buryaad Ulas], "In umbrosis Charatzai, in insulis Selenga, 1829 [fl.], Turczaninov (Herb. Ledebour)", LE (lectotype, designated by Korobkov, 2014: 15).

The names that were misapplied to $A$. umbrosa in some earlier publications are discussed below, in the next section of the article. We decided not to cite here yet any heterotypic synonyms of $A$. umbrosa. An annotated list of heterotypic synonyms (extended synonymy) will be provided later, following the results of the ongoing research of East Asian species of Artemisia found in Europe.

\section{Selected original specimens of Artemisia umbrosa and/or their digital images studied}

In the course of preparation of the present article, Mosyakin and Boiko studied original specimens of A. umbrosa from the historical herbarium collections of Besser and Turczaninow (now in the type collection at $\mathrm{KW}$ ). Available digital images from $\mathrm{G}, \mathrm{H}, \mathrm{K}$, and $\mathrm{P}$ were consulted as well. The list of these specimens is provided below, with brief comments.

KW001000449: label 1, with an original handwritten description by Turczaninow: "Artemisia umbrosa mihi. foliis inferioribus pinnatipartitis, trifurcatis vel superioribus lineari-lanceolatis, integris, subtus cauleque ramoso, albo-pilosis, spicis axillaribus foliosis, floribus sessilibus. In umbrosis ad Selengam et [illegible, some abbreviation]: 1829 Turcz."; label 2, by Turczaninow: "Mihi ad formas $A$. vulgaris $\alpha$ putat. Specimina excepto unica, sunt ramis lateralibus Fol. caulina infer. sunt stipulata. Ramiae omnia simplicissimae. Spiculae nutantes" (image available from: https://plants.jstor.org/stable/10.5555/al.ap. specimen.kw001000449; Fig. 2).

KW001001797: Turczaninow's label: "Artemisia umbrosa mihi. In umbrosis transbaicalensibus 1829 Turcz." (image available from: https://plants.jstor.org/ stable/10.5555/al.ap.specimen.kw001001797).

KW001000453: Besser's label, blue paper (identical to paper used for publication of the Catalogue... by Besser, 1810), on the same sheet with KW001000452: "Artemisia (Abrotanon) vulgaris a A. umbrosa a). Turtschan. In umbrosis ad Selengam. Turtsch. Herb. W. Besser" (image available from: https://plants.jstor.org/ stable/10.5555/al.ap.specimen.kw001000453; Fig. 3).

KW001000452: Besser's label, blue paper, on the same sheet with KW001000453: "Artemisia (Abrotanon) vulgaris $\alpha$ A. umbrosa d) Turc. Ad Selengam Adams (Hbr. Ac. I. Sc.) [from the herbarium of the Imperial Academy of Sciences, St. Petersburg - S.M.]. Herb. W. Besser" (image available from: https://plants.jstor.org/ stable/10.5555/al.ap.specimen.kw001000452; Fig. 3). This specimen was collected on the Selenga by Adams, as indicated in the protologue (Besser, 1832: 52; 1854: 52 ).

G00451804: Turczaninow's label: "Artemisia umbrosa mihi. In umbrosis ad Selengam et [illegible, some abbreviation]. 1829. Turcz."; addition on the label by de Candolle: "M. Turczaninoff à Irkoutsk. 1830 [the date of provenance? - S.M.]"; identification label by de Candolle: "Artemisia vulgaris a umbrosa Bess." (image available from: https://plants.jstor.org/stable/10.5555/ al.ap.specimen.g00451804).

G00451809: Besser's label: "Artemisia vulgaris L. $\alpha$ umbrosa mihi. In umbrosis ad Selengam Ircutiae. 1835 [most probably the date of provenance - S.M.]. Herb. W. Besser" (image available from: https://plants.jstor. org/stable/10.5555/al.ap.specimen.g00451809).

H1437728: "Artemisia umbrosa mihi. A. selengensis $\beta$ Led. Fl. r. [A. selengensis var. $\beta$ umbrosa sensu Ledebour, Flora Rossica - S.M.]. In umbrosis ad Selengam et [illegible, some abbreviation]. 1829. Turcz."; printed label: "Herb. Steven" (image available from: https:// 


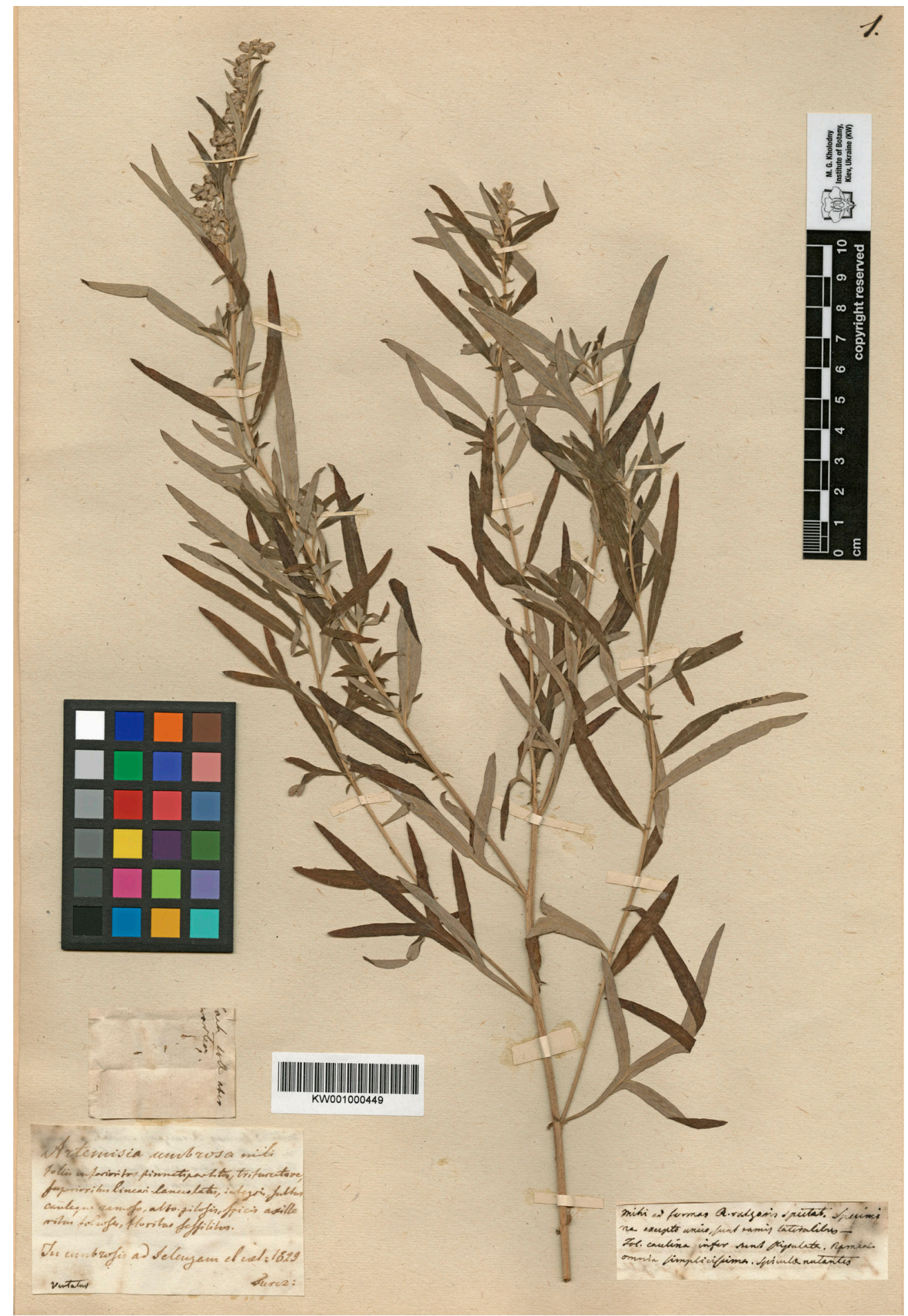

Figure 2. Original specimen of Artemisia umbrosa (KW001000449) from the Turczaninow historical herbarium at KW. See the label information in the text. 


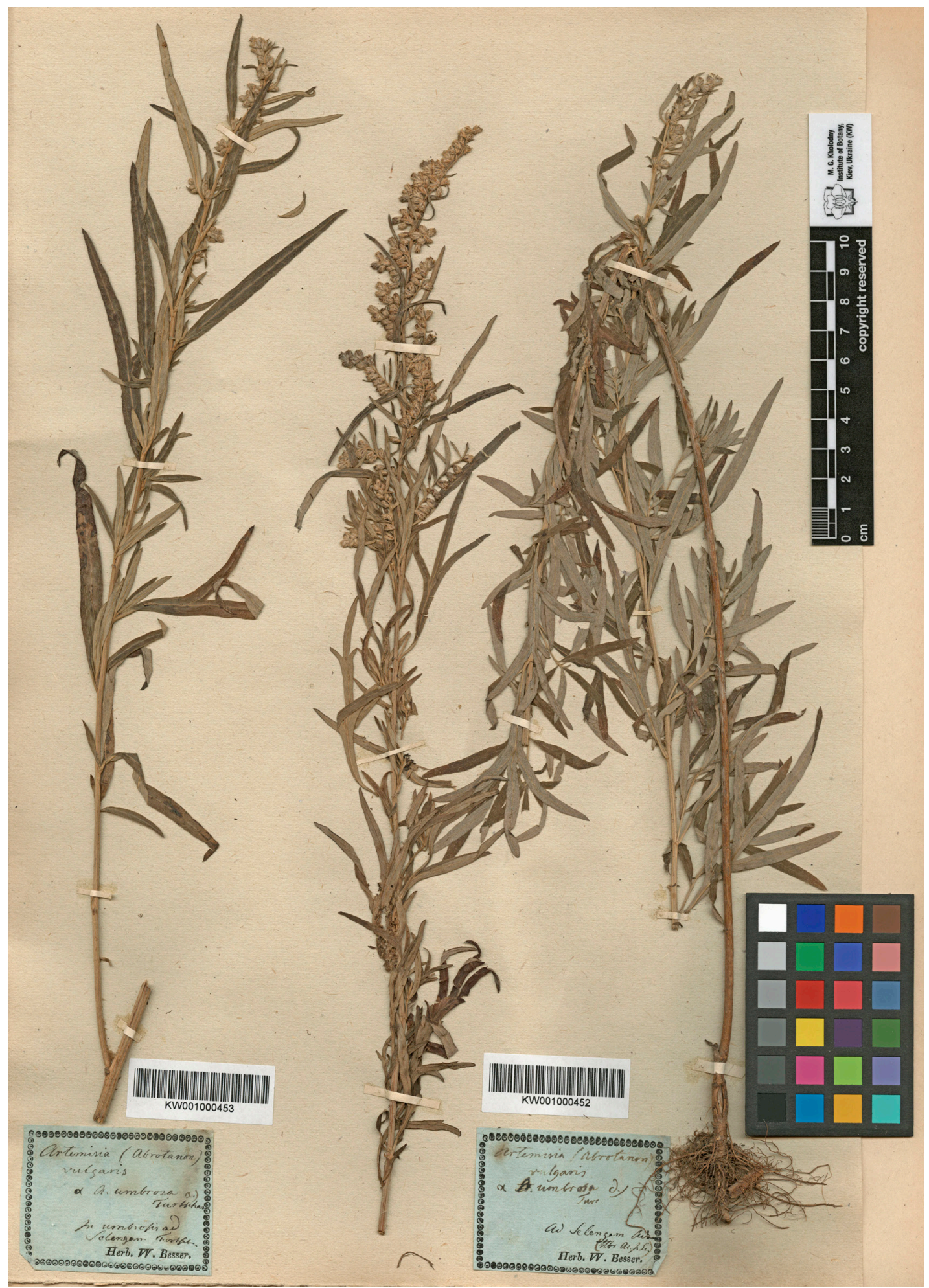

Figure 3. Original specimens of Artemisia umbrosa (KW001000452 and KW001000453, on the same sheet) from the Besser historical herbarium at KW. See the label information in the text. 
plants.jstor.org/stable/10.5555/al.ap.specimen. h1437728).

K000891891: Turczaninow's label: "Artemisia vulgaris var. einerea umbrosa ["cinerea" corrected to "umbrosa", most probably by Turczaninow - S.M.] m. In umbrosis ad Selengam. 1830 [the name of Turczaninow added on the sheet above the label by another hand S.M.]" (image available from: https://plants.jstor.org/ stable/10.5555/al.ap.specimen.k000891891).

K000891890: curatorial label: "Ex herbario horti Petropolitani [printed text]. Artemisia vulgaris L. var. umbrosa Turcz. Ad Selengam. Turczaninoff [printed slip attached to the label: "Received Nov. 1867"]" (image available from: https://plants.jstor.org/stable/10.5555/ al.ap.specimen.k000891890).

P02284369: "Artemisia vulgaris L. var. einerea umbrosa ["cinerea" corrected to "umbrosa", most probably by Turczaninow - S.M.]. In umbrosis ad Selengam. 1830. Turczaninow 1840 [the name of Turczaninow and the date of provenance at $\mathrm{P}$ are added in darker ink and by another hand - S.M.]" (image available from: https://plants.jstor.org/stable/10.5555/al.ap.specimen. p02284369).

\section{Some names misapplied to Artemisia umbrosa}

\section{Artemisia codonocephala Diels}

Probably the first author who synonymized $A$. umbrosa and several other names with $A$. codonocephala (but excluded $A$. dubia sensu stricto!) was Hara (1980), who listed the accepted name ( $A$. codonocephala) and its synonyms, with nomenclatural references, and briefly commented: "After having examined the type material, I came to the conclusion mentioned above. Artemisia dubia Wall. ex Besser (1834) of India is a caespitose suffrutex without creeping rhizome or stolon, and I have cultivated it in Japan for more than 10 years" (Hara, 1980: 326).

Judging from the original description (Diels, 1912: 186-187) and the high-resolution images of the type of $A$. codonocephala (E00417272 and E00417273, 2 sheets, parts of the same gathering/specimen: http:// plants.jstor.org/stable/10.5555/al.ap.specimen. e00417272 and http://plants.jstor.org/stable/10.5555/ al.ap.specimen.e00417273), its isotype (P02284351; http://plants.jstor.org/stable/10.5555/al.ap.specimen. p02284351), and paratype (P02284350; http://plants. jstor.org/stable/10.5555/al.ap.specimen.p02284350), this taxon is not conspecific with $A$. umbrosa; instead, it is closer to $A$. verlotiorum or probably even conspecific with it. Artemisia codonocephala and A. verlotiorum share the following characters: leaves very similar in shape, sparsely pubescent above (becoming glabrous at senescence?), with slightly convolute margins; synflorescences not much branched, with branches often reflexed and curved down ("nodded spikes" in Diels, 1912); rather large and almost sessile erect capitula arranged in rows on synflorescence branches. It seems that $A$. codonocephala has somewhat more pubescent upper surfaces of leaves as compared to A. verlotiorum; however, this character is rather variable and also partly depends on the age of leaves.

In any case, even if $A$. umbrosa and $A$. codonocephala are considered conspecific (which is not the case, in our opinion), the first name is of priority. The name A. codonocephala was used for A. umbrosa in several East European publications (Mosyakin, 1992: 36, "with some doubt"; Yena, 2005, etc.).

Artemisia lavandulifolia DC.

Artemisia lavandulifolia Salisb. (Salisbury, 1796: 191) is illegitimate because it has been published as a superfluous substitute name for $A$. caerulescens L. (Linnaeus, 1753: 848 ). However, the name proposed by Salisbury is valid and because of that the name A. lavandulifolia DC. (de Candolle, 1838: 110; published as "lavandulaefolia", an orthographic variant correctable under Art. 60.8 of the ICN: McNeill et al., 2012) is also illegitimate (Art. 53.1 of the ICN), despite the illegitimacy of its earlier homonym.

Ling et al. (2011) accepted A. lavandulifolia DC. (mainly corresponding in their treatment to A. umbrosa, as accepted here) in a very wide circumscription, including the following names cited as synonyms: "Artemisia araneosa Kitamura; A. argyi H. Léveillé \& Vaniot f. eximia Pampanini; A. clemensiana Pampanini; A. codonocephala Diels; $A$. codonocephala var. maireana Pampanini; A. grisea Pampanini; A. lavandulifolia var. pekinensis Pampanini; A. selengensis Turczaninow ex Besser lusus umbrosa (Turczaninow ex Besser) Regel; A. selengensis var. umbrosa (Turczaninow ex Besser) Ledebour; A. tristis Pampanini; A. vulgaris Linnaeus var. umbrosa Turczaninow ex Besser". At least some of these names are in fact misapplied to A. umbrosa. Distribution data provided by Ling et al. (2011) are also in need of correction: in our opinion, true A. umbrosa most probably occurs only in the northern part of the vast range reported for "A. lavandulifolia" by Ling et al. (1.c.). 
The proper taxonomic application of the name A. lavandulifolia DC. still remains obscure. De Candolle (1838) described his species based on a collection from China by Staunton. Judging from the image of an original specimen (BM000839138, an incomplete specimen, only the upper part of the plant with simple leaves, probably a duplicate of the specimen(s) used by de Candolle, on the same sheet with BM000945896; digital image available from: https://plants.jstor.org/ stable/10.5555/al.ap.specimen.bm000839138), the plant BM000839138 is indeed similar to A. umbrosa, but it might be also a form of $A$. lancea Vaniot (= A. feddei H. Lév. \& Vaniot), to which the fragment BM000945896 probably belongs. In the Flora of the USSR Polyakov (1961: 453) accepted the name A. lavandulifolia, but in fact his concept of that species was directly referable to A. lancea, as it is understood now (accepted as A. fedde $i$ in: Korobkov, 1992: 134; Zuev, 2012: 315). That species was also reported as a rare alien from Eastern Europe (Baranova et al., 1992; Tzvelev, 1994, etc., as "A.feddei") and Romania (Sîrbu, Oprea, 2011, as A. lancea).

In any case, the name proposed by de Candolle is illegitimate and thus it does not affect the nomenclature of currently accepted taxa. Consequently, the true identity of de Candolle's "A. lavandulifolia" is nomenclaturally irrelevant. The name A. lavandulifolia was misapplied to European plants of $A$. umbrosa in several publications (Boiko, 2009; Ostapko et al., 2010), the latest one probably being Sîrbu and Oprea (2011).

\section{Artemisia selengensis Turcz. ex Besser}

As commented above, this name definitely refers to a morphologically very distinct southeastern Siberian and East Asian species with narrow serrate-dentate leaf lobes. It was for the first time misapplied to European plants of $A$. verlotiorum by Bonnet (1883; see also Brenan, 1950). Ledebour (1844) treated $A$. umbrosa as a variety of $A$. selengensis, and that was most probably the reason why Bonnet, who may have used Ledebour's Flora Rossica as a standard taxonomic reference, misapplied that name for plants from France.

Artemisia selengensis was reported originally as occurring "in insulis Selengæ ad Selenginsk Turtsch." by Besser (1832: 50; 1834: 50) and "in insulis Selengæ ad Selenginsk Ircutiæ et pratis humidis Dahuriæ legit cl. Turczaninow" by de Candolle (1838: 112). Turczaninow (1846: 197, 1856) later reported it "in insulis Selengæ prope Selenginsk et in Dahuria orientali prope Czalbuczi", corresponding to the town of Selenginsk (Kabansk District of Buryatia, see above), and the village of Chalbuchi (Чалбучи or Чалбучи-Килга in Russian) in Zabaykalskiy Kray (Trans-Baikal Province), Russia. Korobkov (2014: 14) designated the following specimen from Buryatia as the lectotype: "Lectotypus (Korobkov, hic designatus) et isolectotypi (2): Восточная Сибирь, Бурятия, "In insulis Selengae ad Selenginsk, 1829 [fl.], Turcz." (LE)".

Artemisia dubia Wall. ex Besser: an update on the holotype and isotypes

The name Artemisia dubia Wall. ex Besser (1832: 39; 1834: 39) was (and still is: see below) misapplied to the species accepted here as $A$. umbrosa. That misapplication was probably initiated by Kitamura in his several publications and supported by Ohwi (1965) in his well-known revised English edition of the Flora of Japan (see a nomenclatural summary in Hara, 1980: 326). In fact, A. dubia does not belong to the A. vulgaris aggregate and Artemisia sect. Artemisia, as it has been convincingly demonstrated by Hara (1980), and especially by Ling (1987; see also Ling, 1995; Ling et al., 2011), who placed the species in Artemisia subg. Dracunculus (Besser) Peterm.

Despite the taxonomic and nomenclatural explanation published by Ling (1987) and later cited in Mosyakin (1990), Ling (1995), Ling et al. (2011), Boiko (2012), and in some other sources, cases of that misapplication can be found even in recent literature, in particular, in the standard checklist by Czerepanov (1995). For example, the name "A. dubia" is still accepted for $A$. umbrosa in recent editions of the Flora of the middle zone of the European part of Russia (Mayorov, 2006, 2014) and in many other Russian publications on alien plants (Sukhorukov, 2010; Mayorov et al., 2012; Notov, Notov, 2012; Seregin, 2012, 2014; Tremasova et al., 2013, Vinogradova et al., 2017, etc.).

Besser himself was rather uncertain about the taxonomic position and affinities of his A. dubia, which is evident from the protologue. In particular, Besser (1832: 39; 1834: 39) commented that his specimen was too young for its certain taxonomic placement; he compared his new species with $A$. vulgaris and its relatives (such as $A$. tilesii Ledeb.) but also mentioned its possible placement in the Dracunculus group ("...ut eam ad Dracunculos possim referre").

Ling (1987: 443) cited a specimen from K (K$\mathrm{W}$, referring to the Wallich collection) as an isotype of $A$. umbrosa but did not mention the holotype or lectotype. The digital image of the Kew specimen of A. dubia (K001119019) is available from JSTOR Global 
Plants (https://plants.jstor.org). As it is evident from the protologue, when preparing the description of the species, Besser had at his disposal only one specimen of A. dubia, which originated from Wallich's herbarium collection ["Kamaon in Nepalia Dr. Wallich (v. sp. s. communic. ab. hon. cœtu merc. angl. Ind. orient.)": Besser, 1.c.: 39]. Here the abbreviated text of Besser's note means that he has seen/studied some herbarium specimen provided by/through the Honourable British East India Company; the same provenance is reported for a specimen G00460453 from de Candolle's herbarium in Geneva (see de Candolle, RadcliffeSmith, 1981). It is also reported that "Wilibald Swibert Joseph Gottlieb Besser (1784-1842) of Krzemieniec [Kremenets, Ternopil Region, Ukraine - S.M.] <...> volunteered to work on Wallich's material of the genus Artemisia. This was sent to him, and was incorporated into his Tentamen de Abrotanis in 1832" (de Candolle, Radcliffe-Smith, 1981: 339).

The protologue description of the only specimen studied by Besser (1832: 39-40; 1834: 39-40) perfectly matches the Besser's specimen in the National Herbarium of Ukraine (KW). Consequently, the specimen KW000093841 should be considered the holotype. It was originally in the Besser historical herbarium (KW-BESS) and is deposited now in the type collection at KW. The nomenclatural citation of A. dubia and its type specimens (holotype and two known isotypes) are provided below.

Artemisia dubia Wall. ex Besser, Tentamen de Abrotanis seu de sectione II ${ }^{\text {da }}$ Artemisiarum Linnoei [Moscow]: 39. 1832 (Besser, 1832: 39, preprint); Besser, Nouv. Mém. Soc. Imp. Naturalistes Moscou 3: 39. 1834 (Besser, 1834: 39, bound volume).

Type:-[INDIA: Uttarakhand, or NEPAL?], "Artemisia dubia. Kamaon. Dr. Wallich 31" [1831, date of provenance added by Besser - S.M.]; KW000093841, holotype (image available from: https://plants.jstor. org/stable/10.5555/al.ap.specimen.kw000093841).

Other original specimens (isotypes):

K001119019, isotype: label 1 [upper left corner of the sheet]: "3307/417. Art. dubia Wall. Kamaon RB [Richard Blinkworth - S.M.]"; label 2 [upper right corner of the sheet]: "Artemisia dubia Wall. 3307 [number added in pencil - S.M.]. Kamaon. R. Blinkworth" (image available from: https://plants.jstor.org/stable/10.5555/ al.ap.specimen.k001119019).

G00460453, isotype: "417 Artemisia dubia Wall. Kamaon. Comp. angl. des Indes 1830 [received from the British East India Company in 1830; provenance text added by de Candolle - S.M.]" (image available from: https://plants.jstor.org/stable/10.5555/al.ap. specimen.g00460453).

\section{Acknowledgments}

The authors are grateful to Svitlana I. Antonenko and Tetiana S. Karpiuk (M.G. Kholodny Institute of Botany of the National Academy of Sciences of Ukraine, Kyiv, Ukraine) for scanning the specimens of Artemisia deposited at KW, and to Alisa V. Shumilova (Curatorial Assistant, KW) for her herbarium assistance. Special thanks are due to Cyrille Chatelain (Conservatoire et Jardin botaniques de la Ville de Genève, Geneva, Switzerland) for providing essential information on Verlot's catalogue, and to Peter J. de Lange (Environment and Animal Sciences, Unitec Institute of Technology, Auckland, New Zealand) and Zigmantas Gudžinskas (Nature Research Centre, Institute of Botany, Vilnius, Lithuania) for their valuable comments on the manuscript. The generous support of The Andrew W. Mellon Foundation for herbarium digitization projects at $\mathrm{KW}$ is gratefully acknowledged.

\section{REFERENCES}

[Anonymous in:] Fournier E. (ed.). Revue bibliographique: Catalogue des graines du jardin botanique de Grenoble. Bulletin de la Société Botanique de France, 1876, 23: 3.

[Anonymous in:] Just L. (ed.). Botanischer Jahresbericht: Systematisch geordnetes Repertorium der Botanischen Literatur aller Länder, 1877, vol. 3 [of 1875]: 686.

Baranova O.G., Il'minskikh N.G., Puzyrev A.N., Tuganaev V.V. Checklist of the flora of Udmurtia. Izhevsk: Udmurtian University Publ., 1992, 141 pp. [Баранова О.Г., Ильминских Н.Г., Пузырев А.Н., Туганаев В.В. Конспект флоры Удмуртии. Ижевск: Изд-во Удмуртского университета, 1992, 141 с.].

Baranova O.G., Puzyrev A.N. Conspectus florae Provinciae Udmurtiensis (plantae vasculares). Moscow; Izhevsk: Institute of Computer Research, 2012, 212 pp. [Баранова О.Г., Пузырев А.Н. Конспект флоры Удмуртской Республики (сосудистые растения). М.; Ижевск: Институт компьютерных исследований, 2012, 212 с.].

Besser W. [W.S.J.G.]. Catalogue des Plantes du Jardin Botanique de Krzemieniec en Volhynie. [Kremenets], 1810, 88 pp.

Besser W.S. [W.S.J.G.]. Tentamen de Abrotanis [typo: "Abotanis"] seu de sectione II da Artemisiarum Linncei (Extrait des Nouveaux Mémoires de la Société Impériale des Naturalistes de Moscou, Tome III). [Preprint, Moscow], 1832, 92 pp. + 5 tab. Available from: https://catalog.hathitrust. org/Record/011553698.

Besser W.G. [W.S.J.G.]. Tentamen de Abrotanis seu de sectione II-da Artemisiarum Linnæi. Nouveaux Mémoires de la Société Impériale des Naturalistes de Moscou, 1834, 3: $3-89$. 
Bohnensieg G.C.W., Burck W. (eds). Repertorium Annuum Literaturae Botanicae periodicae, 1879, 5: 146.

Boiko G.V. New data on alien species of the genus Artemisia L. (Asteraceae) in the Ukrainian flora. Ukrainian Botanical Journal, 2009, 66(6): 833-835. [Бойко Г.В. Нові відомості щодо адвентивних видів з роду Artemisia L. (Asteraceae) флори України. Український ботанічний журнал, 2009, 66(6): 833-835].

Boiko A.V. [G.V.]. Artemisia umbrosa (Turch. ex Besser) Pamp., an alien species for the flora of Ukraine. In: Problemy izucheniya adventivnoy $i$ sinantropnoy flor Rossii $i$ stran blizhnego zarubezhya: 4 Mezhdunarodnaya konferentsiya (Izhevsk, 4-7 Dec. 2012). Eds O.G. Baranova, A.N. Puzyrev. Izhevsk, 2012, pp. 27-29. [Бойко А.В. Artemisia umbrosa (Turcz. ex Besser) Pamp. адвентивный вид флоры Украины. В сб.: Проблемы изучения адвентивной и синантропной флор России $и$ стран ближнего зарубежья: 4 международная конференция (Ижевск, 4-7декабря 2012 г.). Ред. О.Г. Баранова, А.Н. Пузырев. Ижевск, 2012, с. 27-29].

Boiko G.V. Identification key for the species of the genus Artemisia L. (Asteraceae) of the flora of Ukraine. Ukrainian Botanical Journal, 2013, 70(4): 479-482. [Бойко Г.В. Ключ для визначення видів роду Artemisia L. (Asteraceae) флори України. Український ботанічний журнал, 2013, 70(4): 479-482].

Bonnet E. Petite Flore Parisienne: contenant la description des familles, genres, espèces et variétés de toutes les plantes spontanées ou cultivées en grand dans la région parisienne. Paris: F. Savy, 1883, xii + 528 pp. http://gallica.bnf.fr/ ark:/12148/bpt6k8890260

Borisova E.A. Dynamics of the alien flora of the Upper Volga region. In: Problemy izucheniya adventivnoy $i$ sinantropnoy flor Rossii i stran blizhnego zarubezhya: 4 Mezhdunarodnaya konferentsiya (Izhevsk, 4-7 Dec. 2012). Eds. O.G. Baranova, A.N. Puzyrev. Izhevsk, 2012, pp. 31-33. [Борисова Е.А. Динамика адвентивной флоры Верхневолжского региона. В сб.: Проблемы изучения адвентивной и синантропной флор России $и$ стран ближнего зарубежья: 4 международная конференция (Ижевск, 4-7 декабря 2012 г.). Ред. О.Г. Баранова, А.Н. Пузырев. Ижевск, 2012, с. 31-33].

Bortnyak M.M., Voytyuk Yu.O. A species new for the flora of Ukraine, Artemisia selengensis Turcz. ex Bess. Ukrainian Botanical Journal, 1991, 48(4): 91. [Бортняк М.M., Войтюк Ю.О. Новий для флори України вид Artemisia selengensis Turcz. ex Bess. Український ботанічний журнал, 1991, 48(4): 91].

Brenan J.P.M. Artemisia verlotorum Lamotte and its occurrence in Britain. Watsonia, 1950, 1(4): 209-223.

Byfield A.J., Baytop A. Three alien species new to the flora of Turkey. Turkish Journal of Botany, 1998, 22: 205-208.

de Candolle A.P. Bulletin bibliographique. Notice sur le progrès de la botanique pendant l'année 1832. (Tiré de Bibliothèque universelle, janvier 1833). Archives de Botanique (Paris), 1833, 2: 22-37.

de Candolle A.P. Prodromus systematis naturalis regni vegetabilis. Parisiis [Paris]: Sumptibus Sociorum Treuttel et Würtz, 1837 [published January 1838], vol. 6, 687 pp. de Candolle R., Radcliffe-Smith A. Nathaniel Wallich, MD, PhD, FRS, FLS, FRGS, (1786-1854) and the Herbarium of the Honourable East India Company, and their relation to the de Candolles of Geneva and the Great Prodromus. Botanical Journal of the Linnean Society, 1981, 83: $325-348$.

Czerepanov S.K. Vascular plants of Russia and adjacent states (the former USSR). Cambridge; New York: Cambridge University Press, 1995, x +516 pp.

Diels L. Plantae Chinenses Forrestianae. Plant discovered and collected by George Forrest during his first exploration of Yunnan and Eastern Tibet in the years 1904, 1905, and 1906: New and imperfectly known species. Notes from the Royal Botanic Garden, Edinburgh, 1912, 5(25): 161-308.

Dubovik O.N., Mosyakin S.L. Artemisia verlotiorum (Asteraceae), a new adventive species of the North Caucasus flora. Botanicheskii Zhurnal, 1991, 76(10): 1408-1411. [Дубовик О.Н., Мосякин С.Л. Artemisia verlotiorum (Asteraceae) - новый адвентивный вид флоры Северного Кавказа. Ботанический журнал, 1991, 76(10): 1408-1411].

Evarts-Bunders P., Evarte-Bundere G., Romanceviča N., Brutāne K., Novicka I., Nitcis M. Retās antropofītu sugas Daugavpils pilsētas florā [in Latvian, with English abstract: Rare anthropophytes in the flora of Daugavpils City]. Latvijas veǵetācija, 2012, 22: 29-43.

Fatare I.J., Gavrilova G.B. Rare species of plants. In: Flora and vegetation of the Latvian SSR. East Latvian geobotanical region. Ed. L.V. Tabaka. Riga: Zinatne, 1985, pp. 142-154. [Фатаре И.Я., Гаврилова Г.Б. Редкие виды растений. В кн.: Флора и растительность Латвийской ССР. Восточно-Латвийский геоботанический район. Ред. Л.В. Табака. Рига: Зинатне, 1985, c. 142-154].

Filatova N.S. Artemisia. In: Plantae Asiae Centralis (secus materies Instituti botanici nomine V.L. Komarovii). Ed. V.I. Grubov. St. Petersburg: Izdatelstvo SPKhFA [St. Petersburg State Chemical-Pharmaceutical Academy Press], 2003, vol. 14a: Compositae (Anthemideae), pp. 55-132. [In Russian: Филатова H.C. Artemisia. В кн.: Растения Центральной Азии: по материалам Ботанического института им. В.Л. Комарова РАН. Ред. В.И. Грубов. Санкт-Петербург: Изд-во СПХФА, 2003, т. 14a: Compositae (Anthemideae), pp. 55-132].

Gabrielian E., Vallès Xirau J.V. New data about the genus Artemisia L. (Asteraceae) in Armenia. Willdenowia, 1996, 26: $245-250$.

Gudžinskas Z.A. New data on the genus Artemisia (Asteraceae) in the Lithuanian flora. Botanicheskii Zhurnal, 1990, 75(8): 1171-1173. [Гуджинскас 3.А. Новые данные о роде Artemisia (Asteraceae) во флоре Литвы. Ботанический журнал, 1990, 75(8): 1171-1173].

Gudžinskas Z. Conspectus of alien plant species of Lithuania. 4. Asteraceae. Botanica Lithuanica, 1997, 3: 335-366.

Gusev Yu.D. New information on adventive flora of various taiga zone's regions of European part of Russia [cited following the English abstract]. Botanicheskii Zhurnal, 1980, 65(2): 249-255. [Гусев Ю.Д. Новые сведения об 
адвентивной флоре разных областей таежной зоны европейской части России. Ботанический журнал, 1980, 65(2): 249-255].

Hara H. Comments on the East Asiatic plants (8). Journal of Japanese Botany, 1980, 55(11): 321-327.

Ignatov M.S., Makarov V.V., Chichev A.V., Shvetsov A.N. Floristic records on railways of Moscow Region. Byulleten Glavnogo botanicheskogo sada, 1983, 129: 43-48. [Игнатов М.С., Макаров В.В., Чичев А.В., Швецов А.Н. Флористические находки на железных дорогах Московской области. Бюллетень Главного ботанического сада, 1983, вып. 129: 43-48].

Ignatov M.S., Makarov V.V., Chichev A.V. A checklist of the alien flora of Moscow Region [English abstract entitled as: Adventive flora of Moscow Province]. In: Investigations of the flora of Moscow Province. Ed. A.K. Skvortsov. Moscow: Nauka, 1990, pp. 5-105. [Игнатов M.C., Макаров В.В., Чичев А.В. Конспект флоры адвентивных растений Московской области. В кн.: Флористические исследования в Московской области. Ред. А.К. Скворцов. Москва: Наука, 1990, с. 5-105].

IPNI. The International Plant Names Index, 2018-onward. Published on the Internet: http://www.ipni.org (Accessed 21 March 2018).

Jäger E.J. Möglichkeiten der Prognose synanthroper Pflanzenausbreitungen. Flora, 1988, 180: 101-131.

Kadžiulienė Ž., Tilvikienè V., Liaudanskienè I., Pocienė L., Černiauskienè Ž., Zvicevicius E., Raila A. Artemisia dubia growth, yield and biomass characteristics for combustion. Zemdirbyste - Agriculture, 2017, 104(2): 99-106.

Khorun L.V., Kazakova M.V., Volosnova L.F. Floristic composition and naturalization of alien species in Ryazan' Region. In: Problemy izucheniya adventivnoy $i$ sinantropnoy flor Rossii $i$ stran blizhnego zarubezhya: 4 Mezhdunarodnaya konferentsiya (Izhevsk, 4-7 Dec. 2012). Eds O.G. Baranova, A.N. Puzyrev. Izhevsk, 2012, pp. 212-215. [Хорун Л.В., Казакова М.В., Волоснова Л.Ф. Флористический состав и натурализация адвентивных видов Рязанской области. В сб.: Проблемы изучения адвентивной и синантропной флор России и стран ближнего зарубежья: 4 международная конференция (Ижевск, 4-7декабря 2012 г.). Ред. О.Г. Баранова, А.Н. Пузырев. Ижевск, 2012, с. 212-215].

Kikodze D., Memiadze N., Kharazishvili D., Manvelidze Z., Mueller-Schaerer H. The alien flora of Georgia. Ed. 2. Fribourg: Université de Fribourg, 2010, 37 pp. [Available from: https://www.unifr.ch/ecology/groupmueller/ assets/files/Final_The $\% 20$ invasive $\% 20$ flora $\% 20$ of $\% 20$ Georgiared_2010_ver2.pdf].

Korobkov A.A. Artemisia. In: Plantae Vasculares Orientis Extremi Sovietici. Ed. S.S. Charkevicz [Kharkevich]. St. Petersburg: Nauka, 1992, vol. 6, pp. 120-161. [Koробков А.А. Artemisia. В кн.: Сосудистые растения советского Дальнего Востока. Ред. С.С. Харкевич. Санкт-Петербург: Наука, 1992, т. 6, с. 120-161].

Korobkov A.A. Type specimens of taxa of Artemisia L. (Asteraceae) from Siberia and the Far East kept in the Herbarium of V.L. Komarov Botanical Institute. Turczaninowia, 2014, 17(2): 5-6. [Коробков А.А. Типовые образцы таксонов рода Artemisia L. (Asteraceae), опи- санных из Сибири и Дальнего Востока, хранящихся в Гербарии Ботанического института им. В.Л. Комарова. Turczaninowia, 2014, 17(2): 5-6].

Kozhin M.N., Kostina V.A., Borovichev E.A., Koryakin A.S., Berlina N.G., Demakhina T.V. Records of alien vascular plants in the Murmansk Province. Byulleten' Moskovskogo Obshchestva Ispytatelei Prirody. Otdel Biologicheskii, 2014, 119(6): 57-58. [Кожин М.Н., Костина В.А., Боровичев Е.А., Корякин А.С., Берлина Н.Г., Демахина Т.В. Находки адвентивных видов сосудистых растений в Мурманской области. Бюллетень МОИП, отд. биол., 2014, 119(6): 57-58].

Krasnoborov I.M. Artemisia. In: Flora Sibiriae. Ed. I.M. Krasnoborov. Novosibirsk: Nauka, 1997, vol. 13, pp. 90-141. [Красноборов И.М. Artemisia. В кн.: Флора Сибири. Ред. И.М. Красноборов. Новосибирск: Наука, 1997, т. 13, с. 90-141].

Kravchenko A.V., Kuznetsov O.L., Timofeeva V.V., Fadeeva M.A., Bobrov A.A., Mironov V.L., Chemeris E.V. Vascular plant species new for Karelia. Trudy Karel'skogo Nauchnogo Tsentra RAN, 2014, 2: 160-164. [Кравченко А.В., Кузнецов О.Л., Тимофеева В.В., Фадеева М.А., Бобров А.А., Миронов В.Л., Чемерис Е.В. Новые для Карелии виды сосудистых растений. Труды Карельского научного центра РАН, 2014, 2: 160-164].

Kryževičienė A., Šarūnaitė L., Stukonis V., Dabkevičius Z., Kadžiulienè Ž. Daugiamečių kiečių (Artemisia vulgaris L. ir Artemisia dubia Wall.) potencialo biokuro gamybai ivertinimas [In Lithuanian, with English abstract: Assessment of perennial mugwort (Artemisia vulgaris L. and Artemisia dubia Wall.) potential for biofuel production]. Žemès Ükio Mokslai [Agricultural Sciences], 2010, 17(1-2): 32-40.

Kurbanov J., Vlasenko G.P. Wild useful plants of Turkmenistan. Problems of Desert Development (Ashkhabad), 2006, 2: 9-12. [Курбанов Дж., Власенко Г.П. Дикорастущие полезные растения Туркменистана. Проблемы освоения пустынь (Ашхабад), 2006, 2: 9-12].

Kuzyarin O.T. Alien species of vascular plants new for Lviv Region. Naukovi Zapysky Derzhavnogo Pryrodoznavchogo Muzеуu (Lviv), 2012, 28: 143-144. [Кузярін О.Т. Нові адвентивні види судинних рослин для Львівської області. Наукові записки Державного природознавчого музею (Львів), 2012, 28: 143-144].

Lamotte M. Recherches sur une nouvelle espèce du genre Artemisia. Compte-Rendu de l'Association Française pour l'Avancement des Sciences, Paris (Compte-Rendu de $5^{\text {me }}$ Session. Clermont-Ferrand, 1876), 1877, 5: 511-513.

Ledebour, C.F. Flora Rossica; sive, Enumeratio plantarum in totius Imperii Rossici provinciis Europaeis, Asiaticis et Americanis hucusque observatarum. Stuttgartiae [Stuttgart]: Sumtibus Librariae E. Schweizerbart, 1844, vol. 2(1), vi +937 pp.

Leonova T.G. Artemisia. In: Grubov V.I. Key to the vascular plants of Mongolia (with an atlas). Leningrad: Nauka, 1982, pp. 245-253. [Леонова Т.Г. Artemisia. В кн.: Грубов В.И. Определитель сосудистых растений Монголии (с атласом). Ленинград: Наука, 1982, с. 245-253]. 
Leonova T.G. Generis Artemisia L. (Asteraceae) florae parte Europaeae URSS conspectus. Novitates Systematicae Plantarum Vascularium, 1987, 24: 177-201. [Леонова Т.Г. Конспект рода Artemisia L. (Asteraceae) флоры Европейской части СССР. Новости систематики высших растений, 1987, 24: 177-201].

Leonova T.G. Artemisia. In: Flora Partis Europaeae URSS. Ed. N.N. Tzvelev. Leningrad: Nauka, 1994, vol. 7, pp. 150-174. [Леонова Т.Г. Artemisia. В кн.: Флора европейской части СССР. Ред. Н.Н. Цвелев. Ленинград: Наука, 1994, т. 7, с. 150-174].

Ling Y.-R. On the status of Artemisia dubia Wall. ex Bess. and A. myriantha Wall. ex Bess. (Compositae). Kew Bulletin, 1987, 42(2): 443-448.

Ling Y.-R. Survey of Artemisia and Seriphidium (AsteraceaeAnthemideae) in the Himalayan Mountains and the South Asian subcontinent. Compositae Newsletter, 1995, 26: 49-60.

Ling Y.-R., Humphries C.J., Gilbert M.G. Artemisia. In: Flora of China. Eds Z.Y. Wu, P.H. Raven, D.Y. Hong. Beijing: Science Press \& St. Louis: Missouri Botanical Garden Press, 2011, vol. 20-21, pp. 676-737.

Linnaeus C. Species Plantarum. Holmiae [Stockholm]: Laurentius Salvius, 1753, vols. 1-2, 1200 pp.

Mamchur Z., Chuba M., Drach Yu. Bryophytes and vascular plants in railway areas of the city of Lviv. Visnyk Lvivs'kogo Universytetu. Ser. Biol., 2017, 75: 54-65. [Мамчур 3., Чуба М., Драч Ю. Мохоподібні та судинні рослини на території залізниці міста Львова. Вісник Львівського університету. Сер. біологічна, 2017, 75: 54-65].

Mavrodiev E.V., Sagalaev V.A., Matveev D.E. On the local flora of Volgograd and its environs. Botanicheskii Zhurnal, 1999, 84(7): 139-143. [Мавродиев Е.В., Сагалаев В.А., Матвеев Д.Е. К флоре Волгограда и его окрестностей. Ботанический журнал, 1999, 84(7): 139-143].

Mayorov S.P. Artemisia. In: Maevskiy [Majevski] P.F. Flora of the middle zone of the European part of Russia. Ed. 10. Moscow: KMK Scientific Press, 2006, pp. 506-510. [Майоров С.П. Artemisia. В кн.: Маевский П.Ф. Флора средней полосы европейской части России. 10-е изд. Москва: Товарищество научных изданий КМК, 2006, c. 506-510].

Mayorov S.P. Artemisia. In: Maevskiy [Majevski] P.F. Flora of the middle zone of the European part of Russia. Ed. 11. Moscow: KMK Scientific Press, 2014, pp. 364-368. [Майоров С.П. Artemisia. В кн.: Маевский П.Ф. Флора средней полосы европейской части России. 11-е изд. Москва: Товарищество научных изданий КМК, 2006, c. 364-368].

Mayorov S.P., Bochkin V.D., Nasimovich Yu.A., Shcherbakov A.V. The alien flora of Moscow and Moscow Region. Moscow: KMK Scientific Press, 2012, 412 pp. +120 color tables. [Майоров С.Р., Бочкин В.Д., Насимович Ю.А., Щербаков А.В. Адвентивная флора Москвы и Московской области. Москва: Товарищество научных изданий КМК, 2012, $412+120$ (цв.) с.].

Mayorov S.R., Volosnova L.F., Daragan E.A. New floristic records in the Kaluga Region. Byulleten' Moskovskogo Obshchestva Ispytatelei Prirody. Otdel Biologicheskii, 1993,
98(6): 118-121. [Майоров С.Р., Волоснова Л.Ф., Дараган Е.А. Новые флористические находки в Калужской области. Бюллетень МОИП, отд. биол., 1993, 88(6): 118-121.].

McNeill J., Barrie F.R., Buck W.R., Demoulin V., Greuter W., Hawksworth D.L., Herendeen P.S., Knapp S., Marhold K., Prado J., Prud'homme van Reine W.F., Smith G.F., Wiersema J.H., Turland N.J. (eds). International Code of Nomenclature for algae, fungi, and plants (Melbourne Code): Adopted by the Eighteenth International Botanical Congress, Melbourne, Australia, July 2011. Regnum Vegetabile, 2012, 154: 1-274.

Morozova O. East Asian species in alien flora of European Russia. Botanica Pacifica, 2014, 3(1): 21-31.

Mosyakin S.L. New and noteworthy alien species of Artemisia L. (Asteraceae) in the Ukrainian SSR. Ukrainian Botanical Journal [Український ботанічний журнал], 1990, 47(4): 10-13.

Mosyakin S.L. Preliminary list of recent additions to the alien flora of Ukraine. Ukrainian Botanical Journal [Український ботанічний журнал], 1991, 48(4): 28-34.

Mosyakin S.L. Floristic notes on alien plants in Kiev. Ukrainian Botanical Journal, 1992, 49(6): 36-39. [Moсякін С.Л. Флористичні нотатки про адвентивні рослини м. Києва. Украӥнський ботанічний жсррнал, 1992, 49(6): 36-39].

Mosyakin S.L. On distribution of Artemisia verlotiorum Lamotte (Asteraceae) and related alien species in Ukraine. Chornomors'kyi Botanichnyi Zhurnal, 2006, 2(1): 93-97. [Мосякін С.Л. До поширення Artemisia verlotiorum Lamotte (Asteraceae) та споріднених адвентивних видів в Україні. Чорноморський ботанічний журнал, 2006, 2(1): 93-97].

Mosyakin S.L., Boiko G.V., Verloove F. Lectotypification of Artemisia mongolica (= A. vulgaris var. mongolica, Asteraceae). Phytotaxa, 2017, 297(3): 257-264. https://doi. org/10.11646/phytotaxa.297.3.4

Mosyakin S.L., Fedoronchuk M.M. Vascular plants of Ukraine. A nomenclatural checklist. Kiev, 1999, xxiii + 345 pp. http://dx.doi.org/10.13140/2.1.2985.0409

Moysienko I.I. Floristic finds in the alien flora of Kherson. Ukrainian Botanical Journal, 2000, 57(4): 424-428. [Мойсієнко I.I. Нові знахідки адвентивних рослин у м. Херсоні. Український ботанічний журнал, 2000, 57(4): 424-428].

Nikitin V.V., Geldikhanov A.M. Identification manual of plants of Turkmenistan. Leningrad: Nauka, 1988, 680 pp. [Никитин В.В., Гельдиханов А.М. Определитель растений Туркменистана. Ленинград: Наука, 1988, 680 c.]

Notov A.A., Notov V.A. Flora of the city of Tver: dynamics of composition and structure during 200 years. Tver: Tver State University Press, 2012, 256 pp. [Нотов A.A., Нотов B.A. Флора города Твери: динамика состава и структуры за 200 лет. Тверь: Тверской гос. ун-т, 2012, 256 с.].

Ohwi J. Flora of Japan: A combined, much revised, and extended translation by the author. Eds F.G. Meyer, E.H. Walker. Washington, D.C.: Smithsonian Institution, 1965, x +1067 pp. 
Ostapko V.M., Boiko A.V., Mosyakin S.L. Vascular plants of the Southeast of Ukraine. Donetsk: Knowledge Publ., 2010, 247 pp. [Остапко В.М., Бойко А.В., Мосякин С.Л. Сосудистые растения Юго-Востока Украины. Донецк: Ноулидж, 2010, 247 с.].

Pampanini R. Contributo alla conoscenza dell' Artemisia Verlotorum Lamotte. Bullettino della Societa' Botanica Italiana, 1923 [vol. of 1923], No. 1-2: 76-90.

Pampanini R. Quinto contributo alla conoscenza dell' "Artemisia Verlotorum" Lamotte. Nuovo Giornale Botanico Italiano, n. s., 1930 [vol. of "1929"], 36(4): 395-547.

Pampanini R. Settimo ed ultimo contributo alla conoscenza dell' "Artemisia Verlotorum" Lamotte. Nuovo Giornale Botanico Italiano, n. s., 1933, 40(2): 183-224.

Perezhogin Yu.V., Kulikov P.V. New species of the flora of Kazakhstan. Vestnik Orenburgskogo Gosudarstvennogo Universiteta, 2017, 3(203): 78-80. [Пережогин Ю.В., Куликов П.В. Новые виды флоры Казахстана. Вестник Оренбургского государственного университета, 2017, 3(203): 78-80].

Polyakov [Poljakov] P.P. Artemisia. In: Flora URSS. Eds B.K. Schischkin [Shishkin], E.G. Bobrov. Moscow; Leningrad: Editio Academiae Scientiarum URSS, 1961, vol. 26, pp. 425-631. [Поляков П.П. Artemisia. В кн.: Флора СССР. Ред. Б.К. Шишкин, Е.Г. Бобров. Москва; Ленинград: Изд-во АН СССР, 1961, т. 26, c. 425-631].

Pritzel G.A. Thesaurus literaturae botanicae omnium gentium: inde a rerum botanicarum initiis ad nostra usque tempora, quindecim millia operum recensens. Lipsiae [Leipzig]: F.A. Brockhaus, 1851, viii +547 pp.

Puzyrev A.N. Supplement to the adventive flora of Udmurtia. Botanicheskii Zhurnal, 1985, 70(2): 268-271. [Пузырев А.Н. Дополнение к адвентивной флоре Удмуртии. Ботанический журнал, 1985, 70(2): 268-271].

Puzyrev A.N. New and rare adventive plants of Udmurtia (according to investigations of 1981-1986). Botanicheskii Zhurnal, 1989, 74(5): 761-765. [Пузырев А.Н. Новые и редкие адвентивные растения Удмуртии (по исследованиям 1981-1986 гг.). Ботанический журнал, 1989, 74(5): 761-765].

Salisbury R.A. Prodromus stirpium in horto ad Chapel Allerton vigentium. Londini [London], 1796, viii + 422 pp.

Seregin A.P. Flora of Vladimir Oblast, Russia: grid data analysis. Moscow: KMK Scientific Press, 2014, 441 pp. +51 color pp. [Серегин А.Р. Флора Владимирской области: анализ данных сеточного картирования. Москва: Товарищество научных изданий КМК, 2014, 441 с., 51 цв. ВКЛ.].

Seregin A.P. (assisted by E.A. Borovichev, K.P. Glazunova, Yu.S. Kokoshnikova, and A.N. Sennikov). Flora of Vladimir Oblast, Russia: Checklist and atlas. Tula: Grif i K., 2012, 620 pp. [Серегин А.П. (при участии Е.А. Боровичёва, К.П. Глазуновой, Ю.С. Кокошниковой, А.Н. Сенникова.). Флора Владимирской области: Конспект и атлас. Тула: Гриф и К., 2012, 620 с.].

Seregin A.P., Yevseyenkov P.E., Svirin S.A., Fateryga A.V. Second contribution to the vascular flora of the Sevastopol area (the Crimea). Wulfenia, 2015, 22: 33-82.
Sîrbu C., Oprea A. New records in the alien flora of Romania (Artemisia argyi, A. lavandulaefolia) and Europe (A. lancea). Turkish Journal of Botany, 2011, 35: 717-728.

Sukhorukov A.P. (Ed.). The identification manual of vascular plants of the Tambov Region. Tula: Grif i K., 2010, 350 pp. [Сухоруков А.П. (ред.). Определитель сосудистых растений Тамбовской области. Тула: Гриф и К., 2010, 350 c.].

Tabaka L., Gavrilova G., Fatare I. Flora of vascular plants of the Latvian SSR. Riga: Zinatne, 1988, 195 pp. [Табака Л., Гаврилова Г., Фатаре И. Флора сосудистых растений Латвийской ССР. Рига: Зинатне, 1988, 195 с.].

Thiers B. Index Herbariorum. A global directory of public herbaria and associated staff. New York Botanical Garden's Virtual Herbarium. 2018-onward. Available from: http://sweetgum.nybg.org/science/ih, accessed 21 March 2018.

Tremasova N.A., Borisova E.A., Borisova M.A. A comparative analysis of invasive components of floras of five regions of the Upper Volga region. Yaroslavskiy Pedagogicheskiy Vestnik. Ser. Estestvennye nauki, 2013, 4: 171-177. [Тремасова Н.А., Борисова Е.А., Борисова М.А. Сравнительный анализ инвазионных компонентов флор пяти областей Верхневолжского региона. Ярославский педагогический вестник. Сер. Естественные науки, 2013, 4: 171-177].

Tretyakov D.I. Artemisia. In: Identification manual of higher plants of Belarus. Ed. V.I. Parfenov. Minsk, Design PRO, 1999, pp. 298-300. [Третьяков Д.И. Artemisia. В кн.: Определитель высших растений Беларуси. Ред. В.И. Парфенов. Минск: Дизайн ПРО, 1999, c. 298-300].

Tretyakova A.S. Alien plants in the flora of Yekaterinburg. In: Problemy izucheniya adventivnoy $i$ sinantropnoy flor Rossii $i$ stran blizhnego zarubezhya: 4 Mezhdunarodnaya konferentsiya (Izhevsk, 4-7 Dec. 2012). Eds O.G. Baranova, A.N. Puzyrev. Izhevsk, 2012, pp. 193-194. [Tpeтьякова А.С. Адвентивные растения во флоре г. Екатеринбурга. В сб.: Проблемы изучения адвентивной и синантропной флор России и стран ближнего зарубежья: 4 международная конференция (Ижевск, 4-7 декабря 2012 г.). Ред. О.Г. Баранова, А.Н. Пузырев. Ижевск, 2012, с. 193-194].

Turczaninow N. [N.S.]. Flora Baicalensi-Dahurica, seu Descriptio plantarum in regionibus Cis- et Transbaicalensibus atque in Dahuria sponte nascentium (continuatio). Ordo Compositae. Bulletin de la Société Imperiale des Naturalistes de Moscou, 1846, 19(3): $135-210$

Turczaninow N. [N.S.]. Flora Baicalensi-Dahurica, seu Descriptio plantarum in regionibus Cis- et Transbaicalensibus atque in Dahuria sponte nascentium. Mosquae [Moscow]: Typis Universitatis Caesareae, 1856, vol. 2, 374 pp.

Tzvelev N.N. Addenda. Species new for the Flora territory. In: Flora Partis Europaeae URSS. Ed. N.N. Tzvelev. Leningrad: Nauka, 1994, vol. 7, pp. 294-295. [Цвелев Н.Н. Дополнение: Новые для территории "Флоры" виды. В кн.: Флора европейской части СССР. Ред. Н.Н. Цвелев. Ленинград: Наука, 1994, т. 7, c. 294-295]. 
Tzvelev N.N. Manual of the vascular plants of North-West Russia (Leningrad, Pskov and Novgorod provinces). St. Petersburg: St. Petersburg State Chemical-Pharmaceutical Academy Press, 2000, 781 pp. [Цвелев Н.Н. Определитель сосудистых растений Северо-Западной России (Ленинградская, Псковская и Новгородская области). Санкт-Петербург: Изд-во СПХФА, 2000, 781 с.].

Uludag A., Aksoy N., Yazlık A., Arslan Z.F., Yazmış E., Uremis I., Cossu T.A., Groom Q., Pergl J., Pyšek P., Brundu G. Alien flora of Turkey: checklist, taxonomic composition and ecological attributes. NeoBiota, 2017, 35: 61-85. https://doi.org/10.3897/neobiota.35.12460

Urgamal M., Oyuntsetseg B., Nyambayar D., Dulamsuren Ch. Conspectus of the vascular plants of Mongolia. Eds Ch. Sanchir, Ts. Jamsran. Ulaanbaatar, Mongolia: Admon Press, 2014, 334 pp.

Vasyukov V.M. Plants of Penza Region (checklist of the flora). Penza: Penza State University Publ., 2004, 184 pp. [Baсюков В.М. Растения Пензенской области (конспект флоры). Пенза: Изд-во Пензенского государственного университета, 2004, 184 с.].

Verloove F. Not every Far Eastern mugwort is Artemisia verlotiorum! In: Verloove F. Manual of the Alien Plants of Belgium. Botanic Garden of Meise, Belgium. 2013-onward. At: alienplantsbelgium.be. Available from: http://alienplantsbelgium.be/content/not-every-far-eastern-mugwort-artemisia-verlotiorum (Accessed 21 March 2018).

Verlot J.-B. Catalogue des graines du Jardin botanique de Grenoble, 1875. Grenoble, 1875 [non vidi].

Verlot J.-B. Artemisia umbrosa Turcz. [Note extraite du Catalogue des graines du Jardin botanique de Grenoble, 1875, par M. J.-B. Verlot]. P. 73 in: [Anonymous]. Notes sur quelques espèces distribuées cette année [1876]. Bulletin de la Société Dauphinoise pour l'Échange des Plantes [Première série de 1874 à 1889], 1876, 3: 69-84.

Vinogradova Y.K., Bochkin V.D., Mayorov S.R., Teplov K.Yu., Barinov A.V. Historical flora of Moscow's Railway Junction (until 2012) [Russian title: Историческая флора железнодорожного узла Московского ме- гаполиса (в границах до 2012 года)]. Hortus Botanicus, 2017, No. 12: 32 pp. http://dx.doi.org/10.15393/ j4.art.2017.3402 (available from: http://hb.karelia.ru/ journal/article_en.php?id=3402).

Volosnova L.F. New species of the flora of Kaluga Region. Biologicheskie Nauki, 1986, No. 8: 71-75. [Волоснова Л.Ф. Новые виды флоры Калужской области. Биологические науки, 1986, №8: 71-75].

Vynaev G.V., Tretyakov D.I. Ecological and geographical characterization of species of the genus Artemisia L. of the flora of the Belorussian SSR. In: Botanika (issledovaniya). Minsk: Nauka i Tekhnika, 1978, issue 20, pp. 101-111. [Вынаев Г.В., Третьяков Д.И. Эколого-географическая характеристика видов рода Artemisia L. флоры БССР. В кн.: Ботаника (исследования). Минск: Наука и техника, 1978, вып. 20, с. 101-111].

Yena A.V. Artemisia codonocephala. In: Greuter W., von Raab-Straube E. (eds). Euro+Med Notulae, 1. Willdenowia, 2005, 35: 223-239.

Yena A.V. Spontaneous flora of the Crimean Peninsula. Simferopol: N. Orianda, 2012, 232 рр. [Ена А.В. Природная флора Крымского полуострова. Симферополь: Н. Оріанда, 2012, 232 с.].

Zuev V.V. Asteraceae/Compositae. In: Conspectus Florae Sibiriae: Plantae Vasculares. Ed. K.S. Baikov. Novosibirsk: Nauka, 2005, pp. 209-242. [Зуев B.B. Asteraceae/Compositae. В кн.: Конспект флоры Сибири: Сосудистые растения. Ред. К.С. Байков. Новосибирск: Наука, 2005, c. 209-242].

Zuev V.V. Artemisia. In: Conspectus Florae Rossiae Asiaticae: Plantae Vasculares. Ed. K.S. Baikov. Novosibirsk: Publishing House of the Siberian Branch of the Russian Academy of Sciences, 2012, pp. 315-323. [Зуев B.В. Artemisia. В кн.: Конспект флоры Азиатской России: Сосудистые растения. Ред. К.С. Байков. Новосибирск: Изд-во Сибирского отделения Российской академии наук, 2012, с. 315-323].

Recommended for publication by

Submitted 04.01.2018

Zigmantas Gudžinskas 
Мосякін С.Л. ${ }^{1}$, Верлоов Ф. ${ }^{2}$, Бойко Г.В. ${ }^{1}$ Правильне авторство та номенклатура Artemisia umbrosa (Asteraceae), з нотатками щодо деяких помилково вживаних назв та поширення виду у Східній Європі. Укр. бот. журн., 2018, 75(3): 213-229.

${ }^{1}$ Інститут ботаніки ім. М.Г. Холодного НАН України вул. Терещенківська, 2, Київ 01004, Україна

${ }^{2}$ Ботанічний сад Мейсе, Нівелаан 38, Мейсе В-1860, Бельгія

Східноазійський вид Artemisia umbrosa (описаний як A. vulgaris var. umbrosa), який також відомий як занесений та натуралізований у деяких європейських країнах, має складну номенклатурну і таксономічну історію. Цю назву неправильно застосовували до споріднених таксонів Artemisia sect. Artemisia, включаючи A. verlotiorum, а декілька інших назв також помилково застосовувалися до цього таксона. Авторство виду A. umbrosa наводилося у літературі по-різному ("Turcz. ex DC.", "Turcz. ex Besser", "(Besser) Turcz. ex DC", "(Turcz. ex DC.) Pamp.", "(Turcz. ex Besser) Pamp." тощо). Ми показали, що базіонім A. vulgaris var. umbrosa був опублікований Бессером у 1832 p. (а не у 1834 р.). Комбінація видового рангу A. umbrosa була дійсно оприлюднена не Пампаніні у 1930 році, а Верло у 1875 році; таким чином, правильне цитування авторства цієї назви - A. umbrosa (Turcz. ex Besser) Turcz. ex Verlot. Незважаючи на те, що Верло невірно застосував назву A. umbrosa до виду, який згодом був описаний як A. verlotiorum, його комбінація є валідною та законною. Стисло розглянуті деякі інші назви, які були неправильно застосовані до A. umbrosa (наприклад, A. codonocephala auct. non Diels, A. dubia auct. non Wall. ex Besser, A. lavandulifolia auct. non DC., nom. illeg., тощо). Обговорюються лектотип та інші оригінальні зразки A. umbrosa (особливо з історичних гербарних колекцій Турчанінова та Бессеpa, KW). Надано стислий огляд флористичних вказівок A. umbrosa у Східній Европі, де вид наводився під кількома назвами.

Ключові слова: Artemisia, Asteraceae, адвентивний вид, номенклатура, систематика, типіфікація
Мосякин С.Л. ${ }^{1}$, Верлоов $Ф .{ }^{2}$, Бойко А.В. ${ }^{1}$ Правильное авторство и номенклатура Artemisia umbrosa (Asteraceae), с комментариями о некоторых ошибочно применяемых названиях и о распространении вида в Восточной Европе. Укр. бот. журн., 2018, 75(3): 213-229.

${ }^{1}$ Институт ботаники им. Н.Г. Холодного НАН Украины ул. Терещенковская, 2, Киев 01004, Украина

${ }^{2}$ Ботанический сад Мейсе, Нивелаан 38, Мейсе В-1860, Бельгия

Восточноазиатский вид Artemisia umbrosa (описан как A. vulgaris var. umbrosa), который также известен как заносный и натурализовавшийся в некоторых европейских странах, имеет сложную номенклатурную и таксономическую историю. Это название неправильно применяли к родственным таксонам Artemisia sect. Artemisia, включая $A$. verlotiorum, а несколько других названий также ошибочно применялись к этому таксону. Авторство вида $A$. umbrosa приводилось в литературе по-разному ("Turcz. ex DC.", "Turcz. ex Besser", "(Besser) Turcz. ex DC", "(Turcz. ex DC.) Pamp.", " (Turcz. ex Besser) Pamp." и т. д.). Мы показали, что базионим A. vulgaris var. umbrosa был опубликован Бессером в 1832 г. (а не в 1834 г.). Комбинация видового ранга A. umbrosa была действительно обнародована не Пампанини в 1930 г., а Верло в 1875 г.; таким образом, правильное цитирование авторства этого названия - A. umbrosa (Turcz. ex Besser) Turcz. ex Verlot. Несмотря на то, что Верло неверно применил название $A$. umbrosa к виду, который позднее был описан как A. verlotiorum, его комбинация валидна и законна. Кратко рассмотрены некоторые другие названия, которые неправильно применялись по отношению к $A$. umbrosa (например, $A$. codonocephala auct. non Diels, $A$. dubia auct. non Wall. ex Besser, A. lavandulifolia auct. non DC., nom. illeg., и др.). Обсуждены лектотип и другие оригинальные образцы $A$. umbrosa (особенно из исторических гербарных коллекций Турчанинова и Бессера, KW). Представлен краткий обзор флористических указаний $A$. umbrosa в Восточной Европе, где вид приводился под несколькими названиями.

Ключевые слова: Artemisia, Asteraceae, адвентивный вид, номенклатура, систематика, типификация 